\title{
Factors Related to Loneliness Among the Elderly Living at Home in Turkey
}

\author{
Türkiye'de Evde Yaşayan Yaşlıların Yalnızlığı ile İlişkili Faktörler
}

Meryem Öztürk Haney ${ }^{l}$, Zuhal Bahar ${ }^{2}$, Ayşe Beşe $e^{2}$, Dilay Açıl ${ }^{1}$, Tuğba Yardımcl ${ }^{3}$, Saadet Çömez ${ }^{4}$

\section{ÖZET}

Amaç/Giriş: Yalnızlık yaşamın her döneminde gelişir ve birçok yaşlı için büyük bir sorundur. Bu çalışmanın amacı yaşlı bireylerde yalnızlık sıklığını belirlemek ve sosyo-demografik özellikler, sağlık durumu, yaşam doyumu ve günlük aktivitelerinin yalnızlığa etkisini değerlendirmektir. Yöntem: Tanımlayıcı ve kesitsel tipteki bu çalışma İzmir ilinde iki kırsal ve bir kentsel bölgede 160 katılımcı ile yürütülmüştür. Veriler sosyo-demografik veri formu, UCLA Yalnızlık Ölçeği, Yaşam Doyum Ölçeği ve Katz Günlük Yaşam Aktiviteleri Ölçeği ve Lawton ve Brody’nin Enstürimental Günlük Yaşam Aktiviteleri Ölçeği ile toplanmıştır. Veriler t testi, Kruskal-Wallis analizi, Anova testi, pearson korelasyon ve çoklu regresyon analizi ile değerlendirilmiştir. Bulgular: Katılımcılarda yalnızlık görülme oranı \%46.9 idi. Katılımcıların evlilik durumu, eğitim durumu, yaşadığı bölge, sağlık durumu, uyku kalitesi, egzersiz yapma durumu ve enstrümental günlük yaşam aktiviteleri durumuna göre yalnızlık puanları arasında fark bulunmuştur. Yaşam doyumu, günlük yaşam aktiviteleri ve enstrümental günlük yaşam aktiviteleri ile yalnızlık arasında ters yönde ilişki saptanmıştır. Sonuç: Yaşlı bakım hizmetleri multidisipliner bir yaklaşım ile sunulmalıdır. Hemşireler uygun hemşirelik girişimleri geliştirmek için özellikle öz bakım kapasiteleri düşük, sosyal etkileşimi azalmış yaşlı bireylerin yalnızlığını değerlendirmelidir.

Anahtar kelimeler: Günlük yaşam aktiviteleri, yaşlı bireyler, yaşam doyumu, yalnızlık.

\begin{abstract}
Aim/background: Loneliness occurs in all stages of life, and a major problem for most of the elderly. To determine the prevalence of loneliness and evaluate the effects of socio-demographic, health characteristics, life satisfaction, activities of daily living and instrumental activities of daily living among elderly people. Methods: This cross-sectional descriptive study was conducted with 160 participants in three regions of İzmir. Measures were included a demographic questionnaire, the UCLA Loneliness Scale, the Life Satisfaction Scale, the Katz Index of Activities of Daily Living and the Lawton and Brody's Instrumental Activities of Daily Living Index. Data were analysed via the independent t-test, Kruskal-Wallis test, ANOVA test, Pearson's correlation and multiple linear regression with stepwise analysis. Results: The loneliness rate was 46.9\% among participants. A great difference existed between loneliness level and marital status, education level, place of residence, selfreported health, self-reported sleep quality, exercise and instrumental activities of daily living. Life satisfaction, activities of daily living and instrumental activities of daily living were negatively associated with loneliness. Conclusion: Elderly care services should be designed with a multidisciplinary approach, and nurses should especially assess loneliness in elderly with low levels of self-care capacity and reduced social contacts to develop appropriate nursing interventions.
\end{abstract}

Keywords: Activities of daily living, elderly people, life satisfaction, loneliness.

Received / Geliş tarihi: 20.01.2017, Accepted / Kabul tarihi: 29.03.2017

${ }^{1}$ Dokuz Eylul University Faculty of Nursing, Public Health Nursing Department

${ }^{2}$ Koç University Nursing School, Public Health Nursing Department

${ }^{3}$ Sinop University School of Health

${ }^{4}$ Mehmet Akif Ersoy University Faculty of Health Sciences

*Address for Correspondence / Yazışma Adresi: Dilay Açıl, Dokuz Eylul University Faculty of Nursing, Public Health Nursing Department, İzmirTÜRKIYE, E-mail: dilayacil@ gmail.com

Haney MÖ, Bahar Z, Beşe A, Açıl D, Yardımcı T, Çömez S. Factors Related to Loneliness among the Elderly Living at Home in Turkey.TJFMPC, 2017;11(2): 71-78.

DOI: $10.21763 /$ tjfmpc. 317717 


\section{INTRODUCTION}

Due to improvements in health and social areas both in developed and in developing countries over the last 25-30 years, the population growth rate has decreased and life expectancy at birth has increased, which has led to an increase in the elderly population. ${ }^{1,2}$ Parallel to the global expectations, the proportion of the elderly population is expected to be greater in the twenty-first century in Turkey. The proportion of the elderly population in Turkey was $8.3 \%$ in 2016 and is expected to rise to $10.2 \%$ in 2023 and to $20.8 \%$ in $2050 .^{2}$ Izmir, the third largest city in Turkey, has an elderly population above the country average of $10.2 \%{ }^{3}$ Traditionally, the elderly in Turkey have preferred to live in the same environment as their children, which has strengthened the ties between the elderly and family members. However, due to factors such as urban expansion and changes in education and employment, people may live in a nuclear family rather than in an extended family, which inevitably forces the elderly live away from the family members. Consequently, loneliness becomes inevitable for the elderly. ${ }^{1}$

Loneliness is a phenomenon that occurs in all stages of life, and it is a major problem for most of the elderly. It is well known that loneliness has serious adverse effects on the health and well-being of the elderly. A recent study have shown that loneliness lays the groundwork for health-related, physical and mental problems in the elderly. ${ }^{4}$ As they age, most elderly individuals suffer multiple losses, such as the loss of a spouse or close friends, talent loss, loss of the usual personal environment, loss of the sense of belonging and loss of job, as well as a reduction in income, decreased movement, increased illness, disability, physical and cognitive deterioration and loneliness., ${ }^{5,6}$ As the elderly population increases and thus advanced age-related disabilities increase, so does the provision of health care and support to the elderly. Studies on the elderly have tended to focus on physical health problems and few have focused on mental health and loneliness. ${ }^{4}$

Previous studies showed, that loneliness rates in the elderly Turkish population ranged between $26.3 \%$ and $61.8 \% .^{7,8}$ Loneliness in old age often leads to negative emotions, reduction in the quality of life, poor prognosis, early institutionalization, increases in the provision of social and health services, mental decline and an increased risk of death. ${ }^{8,9}$ Therefore, identifying loneliness and the factors associated with loneliness in the elderly will contribute to the enhancement of nursing interventions. Thus, this cross-sectional descriptive study was designed (a) to collect data that might serve as a theoretical basis for nursing interventions to provide a higher quality of life to elderly people through the identification of loneliness prevalence, and (b) to evaluate the effects of socio-demographic characteristics, health characteristics, life satisfaction, activities of daily living (ADL) and instrumental activities of daily living (IADL) on loneliness and their correlation among the elderly living at home.

\section{METHODS}

\section{Design}

A cross-sectional, descriptive survey was used in this study.

\section{Participants}

A convenience sample of 160 elderly people who were living in their own homes in one urban region and two rural regions of İzmir, Turkey participated in the study. The inclusion criteria were as follows: being 60 years of age or over, having no cognitive impairment, being able to communicate in Turkish and agreeing to participate in the study.

\section{Materials and procedure}

The researchers collected the data during home visits between April - June 2013. During the home visits, the researchers explained to the elderly the purpose of the study, the details of what participation would entail and the scales to be used in the study. The researchers administered a self-reporting questionnaire. In case an elderly person had difficulty seeing or reading, the researchers read the questionnaire aloud to the participants. Approximately 25-30 minutes were needed to complete the questionnaire.

In the study, the questionnaire on the sociodemographic and health characteristics of the participants, the UCLA Loneliness Scale, the Life Satisfaction Scale, the Katz Index of Activities of Daily Living and Lawton and Brody's Instrumental Activities of Daily Living Scale were administered. The socio-demographic characteristics included age, gender, marital status, the number of households, education level, income level and the place of residence. The health characteristics included perceived health status, number of chronic diseases, duration of the chronic disease(s), continuous medicine use, self-reported quality of sleep and exercising regularly.

The UCLA Loneliness Scale adapted for the Turkish society by Demir, ${ }^{10}$ was used to investigate the participants' loneliness experiences. It consisted of 20 items rated on a 4-point scale, with 10 items worded in a negative direction. The possible 
total score on these items ranged from 20 to 80 . While a total score of 20-34 indicated mild loneliness, 35-48 indicated moderate loneliness, and 49-80 severe loneliness. The reliability of this scale (Cronbach's alpha) was 0.89 .

The participants' life satisfaction was assessed using the Life Satisfaction Scale which was adapted for the Turkish society by Yetim. ${ }^{11}$ It comprised five items rated on a seven-point scale. The possible total score ranged from 5 to 35 , and the higher a participant's score was, the higher his/her life satisfaction was. The reliability of this scale (Cronbach's alpha) was 0.86 .

The participants' functional status was assessed according to their capability of performing daily activities using the Katz Index of Activities of Daily Living. The index was used to assess the participants' capability of performing the following six daily activities: bathing, dressing, toileting, transferring, continence and feeding. ${ }^{12}$ The instrument measured the participants' activities of daily living on a three-point scale: independent (3), semi-independent (2) and dependent (1). While a total score of 0-6 indicated dependent, 7-12 indicated semi-dependent and 13-18 independent. ${ }^{13}$ The reliability of this index (Cronbach's alpha) was 0.93 .

The participants' capability of performing the following tasks was assessed with the Instrumental Activities of Daily Living Index developed by Lawton and Brody ${ }^{14}$ : using the telephone, preparing food, shopping, housekeeping, doing the laundry, taking transportation and handling finances. The instrument measured the participants' activities on a three-point scale: independent (3), semi-independent (2) and dependent (1). A total score of 0-8 indicated dependent, 9-16 semi-dependent and 17-24 independent. ${ }^{13}$ The reliability of this index (Cronbach's alpha) was 0.93 .

\section{Data analysis}

The statistical analysis software package SPSS 15.0 was used to analyse all data. Furthermore, descriptive analysis was used to assess the participants' demographic and health characteristics. The participants' loneliness scores for demographic and health characteristics were compared via the independent t-test and Kruskal-Wallis test and ANOVA test. To determine the relationship between loneliness, life satisfaction, ADL and IADL, Pearson's correlation was used. To identify the important determinants of loneliness in the elderly, multiple linear regression with stepwise analysis was used.

\section{Ethical considerations}

Written permission to carry out the study was obtained from the authorities of the aforementioned regions of Turkey. The aim of the study was expressed to all participants before the study commenced. They were also told that participation was completely voluntary, and that they could withdraw at any time. The participants were informed about the confidentiality of the study as well. The researchers received written and verbal consent from those who volunteered to participate in the study.

\section{RESULTS}

\section{Description of the participants}

The participants' socio-demographic characteristics and the distribution of the UCLA scores are shown in Table 1. The mean age of the participants was $69.87 \pm 7.24$ (ranging from 60 to 93 ). Moreover, $52.5 \%$ of the participants were male, $71.9 \%$ were married, $80 \%$ lived with 2 or fewer people, $69.4 \%$ had attained a low education level, 59.4\% had a moderate-income level and $46.9 \%$ lived in rural areas. Given the socio-demographic characteristics, the results indicate that who were single, uneducated and living in rural areas had statistically significantly higher loneliness scores $(\mathrm{p}<0.05)$.

The health characteristics of the participants and the distribution of loneliness scores are shown in Table 2. Overall, $46.3 \%$ stated that they were in good health. Approximately one third of the participants had two or more chronic diseases for eleven years or more. The majority $(79.4 \%)$ used medication continuously, $58.1 \%$ had good-quality sleep, $47.5 \%$ were exercising (urban area: $31.9 \%$; rural area: $15.6 \%), 3.1 \%$ were semi-dependent in terms of the ADL and $5.6 \%$ were semi-dependent in terms of the IADL. Those whose perceived health status and quality of sleep were poor, who did not exercise and who were semi-dependent in terms of the IADL had statistically significantly higher loneliness scores $(p<0.005)$.

\section{Loneliness among the elderly}

Based on the scores obtained from the UCLA Loneliness Scale, the participants' loneliness levels were classified as mild, moderate and severe. Thirtyfour $(21.3 \%)$ participants suffered from severe loneliness, $41(25.6 \%)$ from moderate loneliness and $85(53.1 \%)$ from mild loneliness. The participants' mean loneliness score was $36.40 \pm$ 12.00 . 


\begin{tabular}{|c|c|c|c|c|}
\hline Variables & $n$ & $\begin{array}{c}\text { UCLA scores } \\
(x \pm S D)\end{array}$ & $p$ & $F / t / x^{2}$ \\
\hline \multicolumn{5}{|l|}{ Age (years) } \\
\hline $60-64$ & 41 & $36.14 \pm 13.43$ & 0.079 & 6.790 \\
\hline $65-74$ & 79 & $34.89 \pm 11.52$ & & \\
\hline 75-84 & 35 & $40.48 \pm 11.03$ & & \\
\hline$\geq 85$ & 5 & $33.60 \pm 9.76$ & & \\
\hline \multicolumn{5}{|l|}{ Gender } \\
\hline Male & 84 & $36.70 \pm 11.82$ & 0.739 & -0.334 \\
\hline Female & 76 & $36.06 \pm 12.27$ & & \\
\hline \multicolumn{5}{|l|}{ Marital Status } \\
\hline Married & 115 & $35.08 \pm 11.83$ & $0.026^{*}$ & -2.240 \\
\hline Single (divorced / widowed) & 45 & $39.75 \pm 11.91$ & & \\
\hline \multicolumn{5}{|l|}{ Number of households } \\
\hline$\leq 2$ & 128 & $36.81 \pm 11.98$ & 0.649 & 0.864 \\
\hline $3-4$ & 25 & $34.36 \pm 10.39$ & & \\
\hline$\geq 5$ & 7 & $36.14 \pm 18.03$ & & \\
\hline \multicolumn{5}{|l|}{ Educational level } \\
\hline No education & 39 & $40.56 \pm 12.22$ & $0.021 *$ & 3.947 \\
\hline Primary school & 72 & $36.12 \pm 11.53$ & & \\
\hline Secondary school and above & 49 & $33.48 \pm 11.80$ & & \\
\hline \multicolumn{5}{|l|}{ Income status } \\
\hline Poor & 42 & $38.50 \pm 12.21$ & 0.339 & 1.090 \\
\hline Fair & 95 & $36.01 \pm 11.26$ & & \\
\hline Good & 23 & $34.17 \pm 14.37$ & & \\
\hline \multicolumn{5}{|l|}{ Place of residence } \\
\hline Rural area & 75 & $42.93 \pm 11.01$ & $0.000 *$ & 7.451 \\
\hline Urban area & 85 & $30.63 \pm 9.69$ & & \\
\hline
\end{tabular}

$* P<0.05$

Relationship between loneliness, life satisfaction, ADL and IADL

The Pearson's correlation results showed that loneliness was negatively correlated with life satisfaction, ADL and IADL. While the most significant correlation was between loneliness and life satisfaction $(\mathrm{r}=-0.331, \mathrm{p}=0.000)$, the least significant correlation was between loneliness and $\operatorname{ADL}(\mathrm{r}=-0.201, \mathrm{p}=0.011)$ (Table 3$)$.

\section{Factors related to loneliness}

Table 4 shows the results of the multivariate linear regression analysis of loneliness with respect to demographic and health characteristics, life satisfaction, ADL and IADL. According to the regression analysis results, self-reported sleep quality, life satisfaction, place of residence and gender were key variables that influenced loneliness among the elderly Turkish population. Further, the analysis results demonstrated that the model used to determine loneliness was significant $(\mathrm{F}=6.068, \mathrm{p}<$ 0.001 ). The adjusted $\mathrm{R}^{2}$ value was 0.353 and the explanatory power was $35.3 \%$. The factors that most strongly affected the participants' loneliness were determined as living in a rural area $(\beta=0.408)$, being male $(\beta=-0.200)$, low life satisfaction $(\beta=0.184)$ and poor sleep quality $(\beta=-0.142)$. 
Table 2 The participants' health-related characteristics and loneliness scores.

\begin{tabular}{|c|c|c|c|c|}
\hline Variables & $n$ & $\begin{array}{c}\text { UCLA scores } \\
\quad(x \pm S D)\end{array}$ & $p$ & $F / t /$ \\
\hline \multicolumn{5}{|c|}{ Self-reported health status } \\
\hline Poor & 16 & $38.87 \pm 13.95$ & $0.004 *$ & 5.726 \\
\hline Fair & 70 & $39.38 \pm 11.61$ & & \\
\hline Good & 74 & $33.04 \pm 11.17$ & & \\
\hline \multicolumn{5}{|c|}{ The number of the chronic diseases } \\
\hline None & 42 & $33.90 \pm 11.55$ & & \\
\hline One & 60 & $37.38 \pm 11.00$ & 0.174 & 1.678 \\
\hline Two & 27 & $34.51 \pm 12.02$ & & \\
\hline Three or more & 31 & $39.51 \pm 13.91$ & & \\
\hline \multicolumn{5}{|c|}{ Duration of the chronic disease (year) } \\
\hline$\leq 5$ & 70 & $36.01 \pm 12.27$ & 0.720 & 0.329 \\
\hline $6-10$ & 38 & $35.84 \pm 12.26$ & & \\
\hline$\geq 11$ & 52 & $37.60 \pm 11.55$ & & \\
\hline \multicolumn{5}{|c|}{ Medication use continuously } \\
\hline Yes & 127 & $37.13 \pm 11.88$ & 0.130 & 1.523 \\
\hline No & 33 & $33.57 \pm 12.20$ & & \\
\hline \multicolumn{5}{|c|}{ Self-reported sleep quality } \\
\hline Good & 93 & $34.39 \pm 11.64$ & $0.028 *$ & 7.175 \\
\hline Fair & 54 & $38.68 \pm 11.45$ & & \\
\hline Poor & 13 & $41.23 \pm 14.49$ & & \\
\hline \multicolumn{5}{|l|}{ Exercising } \\
\hline Yes & 76 & $32.36 \pm 11.23$ & $0.000 *$ & -4.191 \\
\hline No & 84 & $39.98 \pm 11.59$ & & \\
\hline \multicolumn{5}{|c|}{ Activities of daily living level } \\
\hline Semi-dependent & 5 & $44.80 \pm 14.46$ & 0.112 & 1.598 \\
\hline Independent & 155 & $36.12 \pm 36.12$ & & \\
\hline \multicolumn{5}{|c|}{ Instrumental activities of daily living level } \\
\hline Semi-dependent & 9 & $46.00 \pm 16.45$ & $0.013 *$ & 6.304 \\
\hline Independent & 151 & $35.82 \pm 11.50$ & & \\
\hline
\end{tabular}

\begin{tabular}{ccccc}
\hline \multicolumn{5}{l}{ Table 3 Correlations between loneliness and life satisfaction, ADL, IADL } \\
\hline \\
\hline Loneliness & $\mathrm{r}$ & Life Satisfaction & $A D L$ & IADL \\
& $\mathrm{p}$ & -0.331 & -0.201 & -0.207 \\
& 0.000 & 0.011 & 0.009 \\
\hline
\end{tabular}




\begin{tabular}{|c|c|c|c|c|c|c|}
\hline & $B$ & $S E$ & $\beta$ & $t$ & Adj. $R^{2}$ & $F$ \\
\hline Constant & 61.416 & 17.271 & & $3.556^{* *}$ & 0.353 & 6.068 \\
\hline Gender $^{\mathrm{a}}$ & 4.793 & 2.010 & -0.200 & $2.384 *$ & & \\
\hline Place of residence ${ }^{b}$ & 11.701 & 1.738 & 0.489 & $6.733 * *$ & & \\
\hline Sleep quality & -2.638 & 1.320 & -0.142 & $-1.999 *$ & & \\
\hline Life satisfaction & -0.350 & 0.144 & -0.184 & $-2.427 *$ & & \\
\hline
\end{tabular}

$* P=0.05, * * \mathrm{p}<0.001 . \mathrm{SE}$, standard error

${ }^{\text {a }} 0=$ Male, $1=$ Female

\section{DISCUSSION}

This study investigated the loneliness rate among a group of elderly individuals over 60 years of age living at home in rural and urban areas of a large city in the western region of Turkey, and the factors associated with their loneliness. It was determined that the loneliness levels among the elderly individuals was quite high $(46.9 \%$ had moderate to severe loneliness) and that the mean loneliness score was $36.40 \pm 12.00$. In previous studies conducted in Turkey, the loneliness mean scores of the elderly living in two different nursing homes were found to be 51.10 and $39.05,{ }^{15}$ and those of the elderly living at home or in institutions were $40.43 \pm 0.8$ and 45.36 $\pm 11.39 .{ }^{16}$ The loneliness mean score of the elderly living at home and consulted by the Family Healthcare Center was determined to be $51.59 \pm$ 4.44. ${ }^{17}$ In other studies investigating loneliness among the elderly, the prevalence of loneliness in the elderly population living at home was determined to range between $11.4 \%$ and $64.2 \%{ }^{7,8,16}$; however, this rate was determined to be $19 \%$ among the elderly staying in institutions. ${ }^{16}$ The loneliness score obtained in the present study was similar to those obtained in previous studies conducted in Turkey, and the results revealed that a large proportion of the elderly had experienced loneliness. This result also provided a clue as to whether a large elderly group should be monitored for dementia. Thus, Holwerdal et al. ${ }^{17}$ found that a cohort of of elderly people living in community with no dementia enhances the development of dementia in the feeling lonely stage of life. Another systematic review study showed that there is an inverse and significant association between loneliness and cognitive function, intelligence quotient (IQ), processing speed, immediate recall, and delayed recall in the elderly. ${ }^{18}$ In addition, the findings of the present study confirmed the need to focus on loneliness among the elderly and its correlates, such as the socio-cultural structure, economic structure, family structure, health system and social services, and that effective methods should be developed to reduce their loneliness rates.
Previous studies have indicated different results about relationship of gender and loneliness. ${ }^{19,20}$ In our results showed that elderly Turkish men were more likely to suffer loneliness than their female counterparts were. Some other previous studies whose results were similar to ours indicated that elderly men staying in nursing homes ${ }^{15}$ or living in rural areas felt lonelier than their female counterparts did. ${ }^{21}$ Although the role of gender in loneliness among the elderly cannot be fully explained, it is assumed that women leading more active lifestyles and maintaining their social support networks, such as family, friends and neighbours, may help them overcome loneliness more easily. On the one hand, elderly men tend to maintain social contact mostly in public institutions. If a man has led a lifestyle wherein he has been dependent on his wife to maintain the activities of daily living and social support networks, he comes to a serious psychological impasse with the loss of his wife. Due to several factors, such as changes in living conditions, decreased social support and deteriorated health, men experience psychological and physical problems earlier than women do. ${ }^{22}$ Therefore, by enabling them to develop a social support network and providing supportive care services, it will be possible to help elderly people overcome loneliness. This result indicated that nursing interventions for the elderly would strongly influence resolutions to the problems of old age.

Furthermore, elderly people living in rural areas might experience higher rates of loneliness than their urban counterparts due to increased migration from rural to urban areas in Turkey in the last 40 years. ${ }^{1}$ Young people shifting to city centres due to better education and employment opportunities, and leaving the elderly behind, has led to the fragmentation and disintegration of small rural communities. Consequently, the elderly can no longer participate in outdoor activities nor visit their friends and relatives as they did before, and thus they have reduced social contacts and feel lonelier. ${ }^{9}$ This finding suggests that the problems of the elderly living in rural areas of Turkey merit closer attention. 
Another study has revealed that a relationship exists between loneliness and deteriorated sleep quality (adequacy of sleep, falling asleep, duration of sleep, sleep problems and daytime sleepiness). ${ }^{23}$ In our study, the poor sleep quality reported by the elderly was a determinant of loneliness. In their longitudinal observational study conducted with the elderly, McHugh and Lawlor ${ }^{24}$ stated that loneliness increased perceived stress levels and thus reduced sleep quality. Kurina et al. ${ }^{23}$ stated that loneliness adversely affected individuals' perceptions of a safe social environment and thus deteriorated their sleep quality. The results of the present study confirmed that sleep quality and loneliness were closely associated in the elderly and that poor sleep quality posed a risk of loneliness.

Another determinant of loneliness in the present study was decreased life satisfaction. Several studies indicated that whereas living in a family environment, positive family support, having adequate income, positive health perception and social network support provided by friends increased life satisfaction in the elderly, ${ }^{25}$ reduced self-care capacity, feelings of loneliness and anxiety, presence of disability or a chronic disease and low income levels were associated with low levels of life satisfaction. ${ }^{26}$ These results showed that loneliness and life satisfaction are the two concepts that overlap among the elderly, and that these two concepts directly affect each other.

Despite the interesting findings, it is important to address the limitations of this study. First, since the data were collected using the convenience sampling method, the generalizability of the study findings is limited. Second, since a loneliness scale with validity and reliability for the elderly population is not available in the Turkish literature during the study period, the use of a scale that is frequently used in the literature and psychometric evaluation in the Turkish adult population limits the generalizability of the findings. Third, the participants were from one urban area and two rural areas in western Turkey; therefore, the characteristics of the elderly population in these areas may differ from those of the elderly populations in other areas of Turkey.

The present study uncovered high loneliness rates among elderly Turkish people, and the results suggested that living in a rural area, being male and having low life satisfaction and poor sleep quality were the determinants of loneliness in the participants. These results provided basic data for health care and social care providers who work with the elderly, indicating that elder care services should be designed using a multidisciplinary approach. Nurses, family physicians, social workers and other primary care workers should especially assess loneliness among elderly people with low levels of self-care capacity and reduced social contacts, to develop appropriate interventions. Furthermore, they should evaluate the symptoms of loneliness and behaviours reflecting loneliness in elderly people, and provide appropriate interventions so that the elderly can maintain a healthy ageing process. Lastly, for evaluation of loneliness in the elderly is recommended to develop the valid and reliable instruments in Turkish cultural.

\section{ACKNOWLEDGEMENT}

The authors are grateful to all the elderly people who participated in the study.

\section{CONFLICT OF INTEREST}

There are no conflicts of interest.

\section{REFERENCES}

1. The Republic of Turkey, General Directorate of Social Sectors and Coordination. Situation of Elderly People in Turkey and National Action Plan on Ageing 2007. Available from URL: http://www.eyh.gov.tr/upload/Node/8638/files/ Yaslanma_Ulusal_Eylem_Plani.pdf. Accessed 25 September 2014.

2. Turkish Statistical Institute. Population Statistics 2016. Available from URL: http://www.tuik.gov.tr/UstMenu.do?metod=te melist. Accessed 23 February 2017.

3. Turkish Statistical Institute, Izmir District Management, Statistics of Izmir Population with e-mail contact in 01 March 2017.

4. Taube E, Kristensson J, Midlöv P, Holst G, Jakobsson U. Loneliness among older people: results from the Swedish National Study on aging and care - blekinge. The Open Geriatric Medicine Journal 2013; 6:1-10.

5. Bekhet AK, Zauszniewski JA, Nakhla WE. Loneliness: a concept analysis. Nursing Forum 2008;43(4):207-213.

6. Roos V, Malan L. The role of context and the interpersonal experience of loneliness among older people in a residential care facility. Global Health Action 2012; 5:18861.

7. Aylaz R, Aktürk Ü, Erci B, Öztürk H, Aslan H. Relationship between depression and loneliness in elderly and examination of influential factors. Archives of Gerontology and Geriatrics 2012; 55:548-554.

8. Koc Z. Determination of older people's level of loneliness. Journal of Clinical Nursing 2012; 21:3037-3046.

9. Savikko N, Routasalo P, Tilvis RS, Strandberg TE, Pitkala KH. Predictors and subjective causes of loneliness in an aged population. 
Archives of Gerontology and Geriatrics 2005; 41:223-233.

10. Demir A. Validity and reliability of UCLA loneliness scale. Turkish Journal of Psychology 1989; 23:14-18.

11. Yetim Ü. Kişisel projelerin organizasyonu ve örüntüsü açısından yaşam doyumu. Yayınlanmamış Doktora Tezi 1991:68-140, Ege Üniversitesi Sosyal Bilimler Enstitüsü, İzmir, Türkiye.

12. Katz S, Ford AB, Moskowitz RW, Jakson BA, Jaffe MW. Studies of illness in the aged. The Index of ADL: a standardized measure of biological and psychosocial function. JAMA 1963; 185:914-919.

13. Tel H, Güler N, Tel H. Yaşlıların evde günlük yaşam aktivitelerini sürdürme durumu ve yaşam kaliteleri. Hemşirelikte Araştırma Geliştirme Dergisi 2011; 2:59-67.

14. Lawton MP, Brody EM. Assessment of older people: self-maintaining and instrumental activities of daily living. Gerontologist 1969; 9:179-186.

15. Khorshid L, Eşer İ, Zaybak A, Yapucu Ü, Arslan GG, Çınar Ş. The evaluation of loneliness level of elderly individuals residing in rest homes. Turkish Journal of Geriatrics 2004;7(1):45-50.

16. Tel H, Tel H, Sabancioğlu S. Status of maintenance of activities of daily living and experience of loneliness in elder than 60 years old living at home and in institutions. Turkish Journal of Geriatrics 2006;9(1):34-40.

17. Holwerda TJ, Deeg DJ, Beekman AT, van Tilburg TG, Stek ML, Jonker C, et al. Feelings of loneliness, but not social isolation, predict dementia onset: results from the Amsterdam Study of the Elderly (AMSTEL). Journal of Neurology, Neurosurgery \& Psychiatry 2014;85(2):135-142.

18. Boss L, Kang DH, Branson S. Loneliness and cognitive in the older adult: a systematic review. International Psychogeriatrics 2015;24(4):541553.

19. Hacihasanoğlu R, Yildirim A, Karakurt P. Loneliness in elderly individuals, level of dependence in activities of Daily living (ADL) and influential factors. Archives of Gerontology and Geriatrics 2012; 54:61-66.

20. Ünal $G$, Bilge A. The evaluation of the loneliness, depression and cognitive function in older age group. Turkish Journal of Geriatrics 2005; 8:89-93.

21. Wang G, Zhang X, Wang K, Li Y, Shen Q, Ge $X$, Hang W. Loneliness among the rural older people in Anhui, China: prevalence and associated factors. International Journal of Geriatric Psychiatry 2011; 26:1162-1168.
22. Stevens N. Gender and adaptation to widowhood in later life. The International Journal of Aging and Society 1995; 15:37-58.

23. Kurina LM, Knutson KL, Hawkley LC, Cacioppo JT, Lauderdale DS, Ober C. Loneliness is associated with sleep fragmentation in a communal society. Sleep 2011;34(11):1519-1526.

24. McHugh JE, Lawlor BA. Perceived stress mediates the relationship between emotional loneliness and sleep quality over time in older adults. British Journal of Health Psychology 2013; 18:546-555.

25. Roh S, Lee YS, Lee KH, Shibusawa T, Yoo GJ. Friends, depressive symptoms, and life satisfaction among older Korean Americans. Journal of Immigrant Minority Health 2014;17(4):1091-7. DOI: 10.1007/s10903-0140021-z.

26. Jivraj S, Nazroo J. Determinants of socioeconomic inequalities in subjective wellbeing in later life: a cross-country comparison in England and the USA. Quality of Life Research 2014;23 (9): 2545-58. DOI: 10.1007/s11136014-0694-8. 